\title{
Studi Perencanaan dan Monitoring System Pembangkit Listrik Tenaga Surya di Remote Area
}

\author{
Sofia Ariyani ${ }^{1}$, Darma Arif Wicaksono², Fitriana ${ }^{3}$, Rachmad Taufik ${ }^{4}$, Germenio $^{5}$ \\ 1,2,3,4,5Program Studi Teknik Elektro, \\ Fakultas Teknik, \\ Universitas Muhammadiyah Jember, Jember \\ ${ }^{1}$ sofiaariyani@unmuhjember.ac.id, 2darmaarifwicaksono@unmuhjember.ac.id, \\ ${ }^{3}$ fitriana@unmuhjember.ac.id, ${ }^{4}$ rachmadtaufik20@gmail.com, ${ }^{5}$ germenio05@gmail.com
}

\begin{abstract}
Abstrak
Instalasi pembangkit listrik dengan memanfaatkan sumber energi terbarukan merupakan solusi untuk pemenuhan kebutuhan energi listrik terutama pada daerah tertinggal, terdepan, dan terluar (3T) atau remote area. Pemenuhan kebutuhan listrik pada daerah 3T atau remote area dapat dilakukan dengan menggali potensi energi terbarukan dan memanfaatkannya dalam sebuah sistem pembangkit listrik. Potensi sinar atau cahaya matahari di sebagian besar wilayah Indonesia, terutama Indonesia timur yang kebutuhan listrik belum secara merata tersedia. Selain itu faktor lain bahwa Indonesia adalah negara tropis mendukung pemanfaatan energi matahari menjadi energi listrik. Pembangkit Listrik Tenaga Surya (PLTS) merupakan salah satu solusi yang dapat digunakan pada sebagian besar wilayah Indonesia. Pada penelitian ini dibahas tentang perencaan PLTS pada daerah 3T secara off-grid termasuk juga perbandingan terhadap tarif dasar listrik (TDL) PLN 450 VA. Selain itu dilengkapi dengan divais monitoring performa PLTS pada remote area berupa data tegangan, arus, dan daya sehingga akan membantu operator dalam melakukan maintenance. Proses monitoring dilakukan dengan menggunakan modul IoT ESP8266 dengan kombinasi Arduino Mega 2560. Objek ukur yang digunakan pada penelitian ini adalah PLTS dengan sistem off-grid skala laboratorium sebagai proyeksi kelistrikan remote area yang tidak terhubung dengan listrik jala-jala PLN.
\end{abstract}

Kata kunci: PLTS, sistem monitoring, IoT ESP8266, daerah 3T.

\begin{abstract}
Installing power plants by utilizing renewable energy sources is a solution to meet the needs of electrical energy, especially in disadvantaged, frontier, and outermost (3T) or remote areas. Fulfilling electricity needs in 3T areas or remote areas can be done by exploring the potential for renewable energy and utilizing it in a power generation system. The potential for sunlight or sunlight in most parts of Indonesia, especially eastern Indonesia, where electricity needs are not evenly available, besides that, another factor is that Indonesia is a tropical country that supports the use of solar energy into electrical energy. Solar Power Plant (PLTS) is a solution that can be used in most parts of Indonesia. This research discusses the planning of PLTS in the remote area as off-grid system, including the comparison to the basic electricity tariff (TDL) of PLN 450 VA. In addition, it is equipped with a PV mini-grid performance monitoring device in the remote area in the form of voltage, current, and power data so that it will assist operators in carrying out maintenance.. The monitoring process was carried out using the IoT ESP8266 module with a combination of Arduino Mega 2560. The measuring object used in this research is PLTS with a laboratory
\end{abstract}


scale off-grid system as an electricity projection for remote areas that are not connected to the PLN grid.

Keywords: Solar power plant, monitoring system, IoT ESP8266, remote area

\section{Pendahuluan}

Pemerataan ketersediaan listrik di Indonesia merupakan hal yang krusial untuk dilakukan. Kondisi demografis wilayah Indonesia yang tersusun atas 17.466 pulau membuat pemenuhan kebutuhan listrik menjadi hal yang sulit untuk dilakukan secara menyeluruh. Pada pulau besar dan padat penduduk seperti pulau Jawa, kebutuhan listrik dapat dimanfaatkan oleh sebagian besar masyarakat dengan mudah, hal ini karena pulau Jawa merupakan tempat dilakukan kegiatan pemerintahan, pendidikan yang baik, dan kemudahan akses. Sedangkan pada beberapa daerah yang terletak di bagian pinggir atau luar Indonesia atau disebut dengan daerah tertinggal, terdepan dan terluar (3T) atau remote area akses listrik masih terbatas pada waktu-waktu tertentu. Pemenuhan kebutuhan listrik saat ini diprioritaskan pada daerah timur Indonesia, seperti Papua Barat, Nusa Tenggara Timur, dan Maluku.

Daerah yang belum teraliri listrik secara penuh adalah daerah yang berpotensi untuk dibangun pembangkit listrik energi terbarukan. Potensi panas matahari Indonesia yang merupakan negara tropis secara massif dapat dimanfaatkan sebagai suplai listrik untuk daerah 3T. Potensi cahaya matahari dapat secara langsung dimanfaatkan menjadi energi listrik dengan memanfaatkan panel surya sebagai media pengubah cahaya matahari menjadi energi listrik atau Pembangkit Listrik Tenaga Surya (PLTS).

Instalasi PLTS merupakan jenis pembangkit lsitrik yang mudah dilakukan, karena PLTS tidak membutuhkan peralatan yang susah namun tetap harus dipantau untuk mengetahui performa dari PLTS tersebut. PLTS terbagi atas dua sistem, yaitu sistem ongird dan off-grid. Sistem on-grid adalah PLTS yang dikoneksikan secara langsung dengan listrik jala-jala PLN. Sedangan listrik off-grid adalah instalasi PLTS yang berdiri tanpa listrik PLN, backup energi dilakukan dengan memanfaatkan sumber energi lain seperti baterai. Penelitian yang dilakukan adalah studi ekonomi terhadap instalasi PLTS off-grid yang berpotensi dipasang pada daerah $3 \mathrm{~T}$ atau remote area. Referensi [3] telah melakukan studi ekonomi terhadap pemasangan PLTS skala besar 11,4 kW bahwa analisa ekonomi menyatakan kelayakan terhadap instalasi PLTS, kekurangan dari penelitian tersebut adalah belum adanya perbandingan dengan listrik PLN yang sudah tersedia.

Proses maintenance PLTS penting dilakukan untuk melihat apakah daya listrik yang dihasilkan sesuai dengan profil peralatan yang diharapkan. Referensi [7] melakukan penelitian tentang sistem monitoring PLTS on-grid pada rooftop. Dengan adanya sistem tersebut, operator dapat melihat performa dari PLTS tanpa harus datang ke lokasi. Dengan dasar penelitian Kadir dan Habib, pada penelitian ini dilakukan studi ekonomi PLTS off-grid skala laboratorium 200 Watt Peak (Wp) sebagai proyeksi kelistrikan pada daerah $3 \mathrm{~T}$ atau remote area yang dilengkapi dengan sistem monitoring dengan memanfaatkan teknologi Internet of Things (IoT) untuk PLTS off-grid untuk memudahkan proses maintenance yang dapat membantu kerja operator dalam memantau performa PLTS. 


\section{Metodologi Penelitian}

\subsection{Studi Ekonomi Instalasi PLTS off-grid}

Perencanaan perancangan PLTS off-grid adalah studi ekonomi bagaimana PLTS offgrid dapat digunakan sebagai solusi pemenuhan kebutuhan listrik pada daerah 3T atau remote area. Studi ekonomi yang termasuk pada penelitian adalah sebagai berikut:

1) Biaya Instalasi Awal (S)

Biaya instalasi awal adalah biaya keseluruhan komponen yang digunakan sebagai penyusun PLTS off-grid pada penelitian yang dilakukan.

2) Biaya Pemeliharaan dan Operasional (O\&M)

Besaran biaya operasional ditentukan $1 \%$ dari biaya instalasi awal. Hal ini berpedoman pada besaran biaya operasional adalah 1\%-2\% dari biaya intalasi selama 1 tahun. Operasional PLTS off-grid diasumsikan bertahan selama 10 tahun dan rtingkat suku bunga sebesar 4,5\% dengan mempertimbangkan umur panel surya, baterai, dan perangkat lain.

$$
\begin{aligned}
& \text { O\&M (pertahun })=1 \% \times \text { Biaya Investasi Awal } \\
& \mathrm{O} \& \mathrm{M}(p)=\mathrm{O} \& \mathrm{M}\left[\frac{(1+i)^{n}-1}{i(1+i)^{n}}\right]
\end{aligned}
$$

Keterangan:

O\&M pertahun = Biaya pemeliharaan dan operasional pertahun

O\&M $(p)=$ Biaya pemeliharaan dan operasional sampai masa hidup peralatan

$n=$ tahun masa hidup peralatan

$i=$ presentasi kenaikan biaya pemeliharaan dan operasional

3) Biaya Siklus Hidup (LifeCycle Cost)

Biaya siklus hidup adalah Analisa biaya keseluruhan baik dari investasi dan juga pemeliharaan selama kurun waktu tertentu.

$$
\text { Life Cycle Cost }(\mathrm{LCC})=\mathrm{S}+\mathrm{O \& M}(\mathrm{p})
$$

4) Faktor Pemulihan Modal (CRF)

Faktor pemulihan modal digunakan untuk merubah biaya tahunan yang dikeluarkan terhadap instalasi PLTS terhadap biaya pembayaran pertahun dalam kWh.

$$
\mathrm{CRF}=\left[\frac{i(1+i)^{n}}{(1+i)^{n}-1}\right]
$$

5) Biaya Energi PLTS (COE)

Biaya energi adalah Analisa kelayalan sebuah PLTS untuk disebut layak atau tidak terhadap biaya hidup dan Kwh Produksi selama 1 tahun

$$
\mathrm{COE}=\frac{L C C \times C R F}{k W h}
$$

6) Biaya Listrik PLN beban 450 VA

Biaya Listrik PLN dihitung untuk mengetahui perbedaan TDL antara listrik PLTS dan PLN. Besaran listrik PLN diasumsikan sama dengan lisrik PLTS untuk 
menyamakan faktor pembagi. Kenaikan listrik PLN dalam 10 tahun dipertimbangkan sebagai $5 \%$ dan biaya abonemen adalah biaya dasar pada beban listrik PLN. Sehingga persamaan biaya listrik PLN adalah sebagai berikut:

kWh PLN = Biaya perbulan $\times 12($ bulan $) \times 10($ tahun $) \times\left[\frac{(1+i)^{n}-1}{i(1+i)^{n}}\right]+($ abonemen $\times 12 \times 10)$

Keterangan :

Biaya perbulan = biaya perbulan PLN

Abonemen $=$ Rp. 8.000 untuk listrik 450 VA

\subsection{Perancangan Sistem Monitoring}

Proses monitoring sistem PLTS off-grid berbasis IoT yang digunakan sebagai proyeksi keadaan nyata dari daerah remote area menggunakan beberapa komponen pendukung sebagai berikut:

\section{Sensor PZEM 004T}

Dalam mengukur besaran arus, tegangan, daya dan akumulasi energi beban yang bekerja pada sistem off-grid menggunakan sensor PZEM 004T. Penggunaan sensor PZEM 004T karena sensor ini memiliki performa yang baik dalam sensor kelistrikan AC.

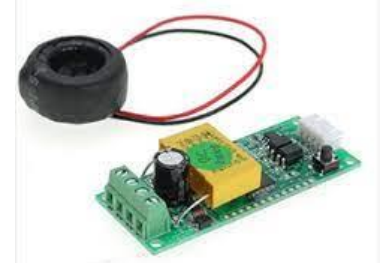

Gambar 1. Sensor PZEM-004t

2. Mikrokontroler ATMega 2560

Proses otomasi sistem yang digunakan pada monitoring PLTS off-grid adalah mikrokontroler ATMega 2560. Mikrokontroler digunakan untuk proses pemrograman keseluruhan sistem berupa pembacaan data dari sensor, juga integrasi dengan modul IoT.

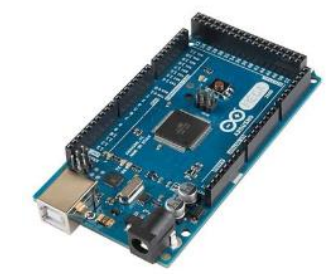

Gambar 2. Arduino Mega 2560

3. Modul Internet of Things (IoT)

Monitoring dilakukan dengan menggunakan teknologi IoT. Dengan memanfaatkan modul IoT ESP8266, data yang disensor dapat dilihat dari perangkat telepon Android pengguna dimanapun berada. Syarat untuk melakukan proses monitoring adalah ketersediaan jaringan internet. 


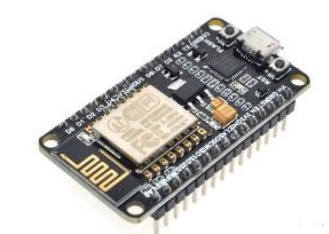

Gambar 3. Modul IoT ESP 8266

4. Inverter off-grid 500 watt

Peralatan yang digunakan untuk merubah listrik DC menjadi listrik AC pada penelitian ini adalah inverter off-grid 500 watt. Kondisi ini diproyeksikan sebagai kondisi nyata ketika sumber energi terbarukan PLTS adalah listrik DC, sedangkan peralatan kelistrikan rumah tangga adalah AC.

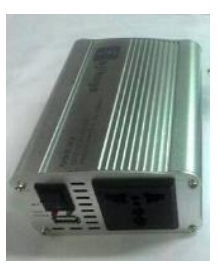

Gambar 4. Inverter 500 W

\section{Baterai}

Karena ketersediaan listrik PLTS hanya berlangsung ketika tersedia cahaya matahari, maka untuk memaksimalkan kinerja PLTS off-grid pada malam hari ditambahkan energi penyimpanan. Energi penyimpanan pada penelitian ini adalah baterai $12 \mathrm{~V} 7,2 \mathrm{Ah}$.

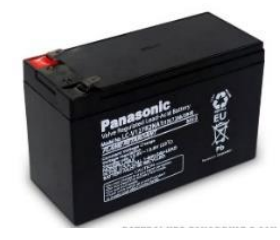

Gambar 5. Baterai 12V 7,2 Ah

\section{Modul Uji dan Beban}

Pengambilan data penelitian dilakukan pada modul PLTS off-grid skala laboratorium dengan panel surya 200 Watt peak (Wp), inverter 500 Watt, baterai 12 V 5 A, dengan lampu LED sebagai beban listriknya. 


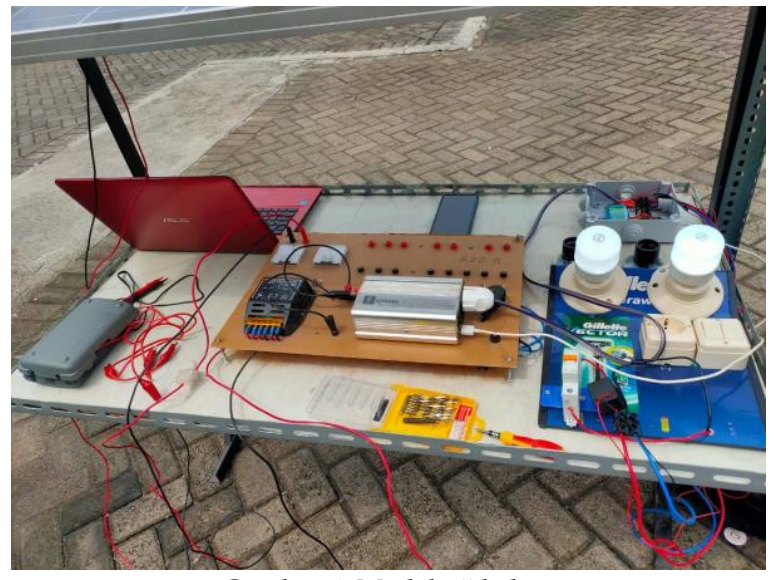

Gambar 6. Model uji beban

\subsection{Diagram Alir Sistem Monitoring}

Dalam proses perancangan sistem monitoring PLTS off-grid, berikut pada Gambar 7 adalah diagram alir yang digunakan.

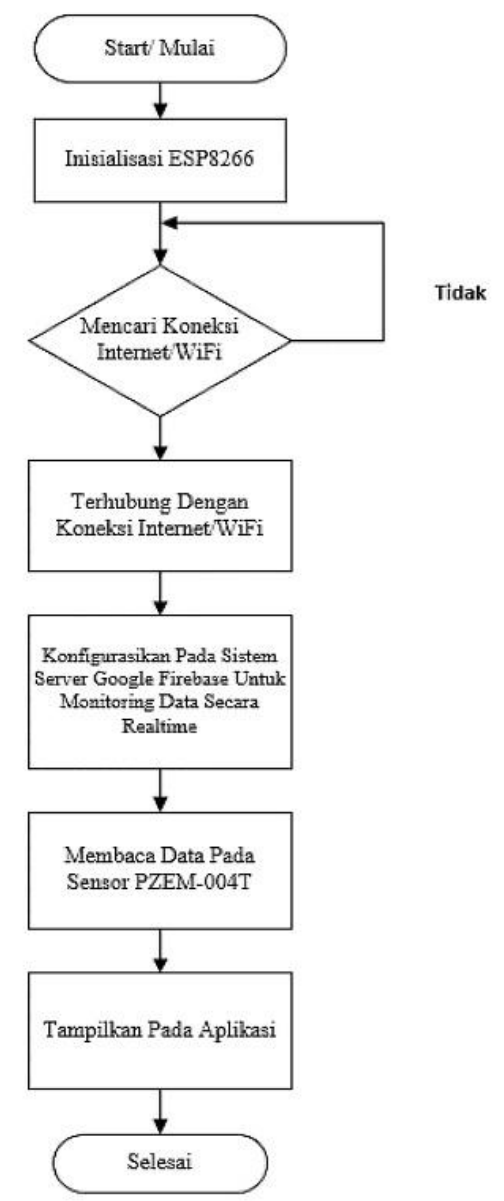

Gambar 7. Diagram alir sistem monitoring berbasis IoT

Modul PLTS off-grid skala laboratorium yang digunakan sebagai model pengujian diperlihatkan pada Gambar 8 berikut. 
Studi Perencanaan dan Monitoring System Pembangkit Listrik Tenaga Surya di Remote Area Sofia Ariyani, Darma Arif Wicaksono, Fitriana, Rachmad Taufik, Germenio

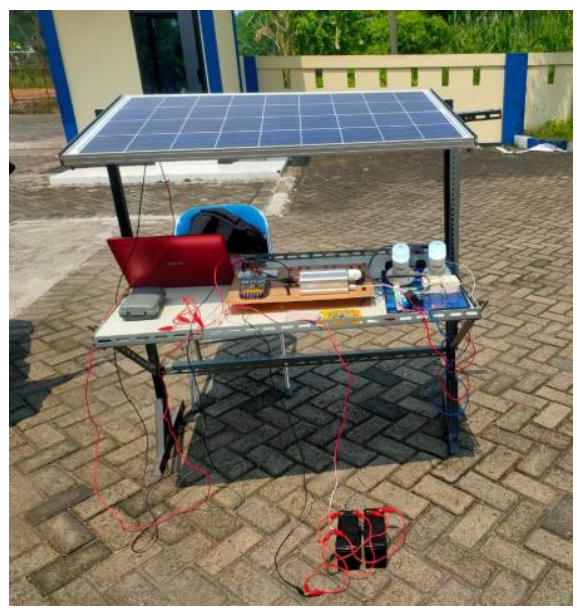

Gambar 8. Modul PLTS off-grid sebagai model pengujian

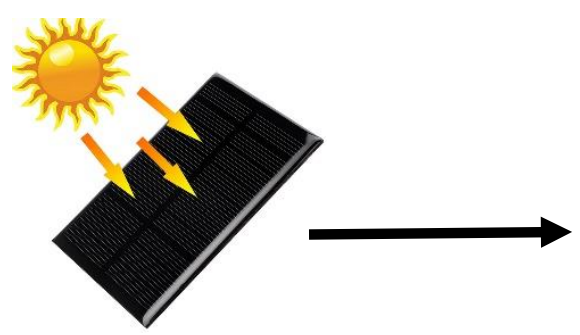

Panel surya
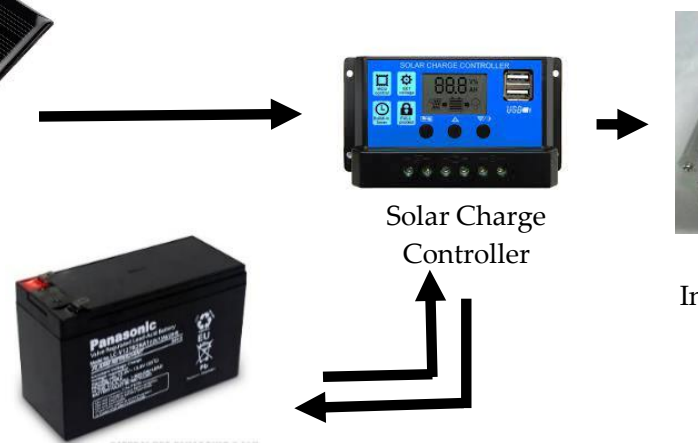

Baterai

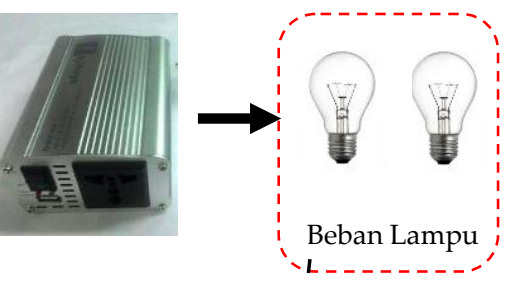

Inverter DC-AC

I

I

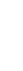

1

i

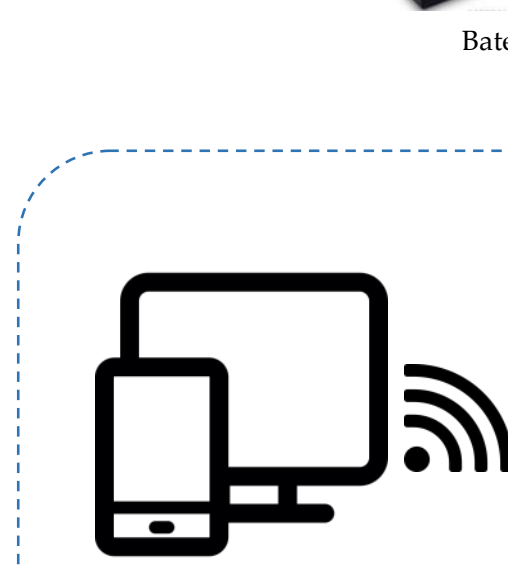

Komputer/ Handphone

Modul IoT ESP8266

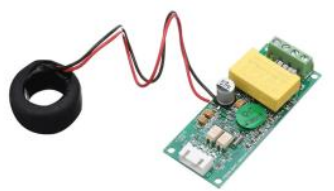

Sensor PZEM-004t

Gambar 9. Perancangan sistem PLTS off-grid terintegrasi IoT 


\section{Hasil dan Pembahasan}

Penyajian data hasil penelitian disusun menjadi 2 tahap, yaitu tahap perencanaan perancangan PLTS off-grid kemudian dilengkapi dengan data penelitian sistem monitoring PLTS off-grid berbasis IoT. Berikut adalah data perancangan instalasi PLTS offgrid memiliki faktor analisa ekonomi yang disajikan pada data berikut:

\subsection{Skema Sistem PLTS Off-grid}

Penjelasan pertama terkait data adalah studi ekonomi terkait pemasangan PLTS offgrid seperti yang dijelaskan pada sub bab 2 .

1) Biaya Instalasi Awal (S)

Besaran biaya instalasi awal terdiri dari jumlah nominal untuk pengadaan peralatan penyusun seperti pada sub bab 2.

Tabel 1. Biaya investasi awal

\begin{tabular}{|l|c|}
\hline \multicolumn{1}{|c|}{ Komponen } & Harga $(\mathrm{Rp})$ \\
\hline Panel Surya 200 Wp & 1.000 .000 \\
\hline Inverter off-grid 500 W & 200.000 \\
\hline Baterai 12 V, 7,2 Ah & 300.000 \\
\hline Solar Charge Controler & 100.000 \\
\hline Beban lampu 16 watt & 70.000 \\
\hline Jumlah & 1.670 .000 \\
\hline
\end{tabular}

Sumber : Tokopedia, diakses 24/9/21 pkl. 11.04 WIB

Sehingga total biaya investasi awal (S) untuk listrik $200 \mathrm{Wp}$ adalah Rp. 1.670.000

2) Biaya Pemeliharaan dan Operasional (O\&M)

$$
\begin{aligned}
& \begin{aligned}
\text { O\&M (pertahun }) & =1 \% \times(\mathrm{S}) \\
& =1 \% \times \text { Rp. } 1 \cdot 670.000 \\
& =\text { Rp. } 16.700
\end{aligned} \\
& \begin{aligned}
\text { O\&M (p) }=\text { O\&M }\left[\frac{(1+i)^{n}-1}{i(1+i)^{n}}\right] \\
=\text { Rp. } 16.700\left[\frac{(1+0,045)^{10}-1}{0,045(1+0,045)^{10}}\right] \\
=\text { Rp. } 16.700\left[\frac{0,5529}{0,069}\right] \\
=\text { Rp. } 133.817,83
\end{aligned}
\end{aligned}
$$

3) Biaya Siklus Hidup (LCC)

$$
\begin{aligned}
\text { Life Cycle Cost (LCC) } & =\mathrm{S}+\mathrm{O} \& \mathrm{M}(\mathrm{p}) \\
& =\text { Rp. } 1.670 .000(\mathrm{Rp} .133 .817,83) \\
& =\text { Rp. } 2.234 .743,9
\end{aligned}
$$


4) Faktor Pemulihan Modal (CRF)

$$
\begin{aligned}
\mathrm{CRF} & =\left[\frac{i(1+i)^{n}}{(1+i)^{n}-1}\right] \\
& =\left[\frac{0,045(1+0,045)^{10}}{(1+0,045)^{n}-1}\right]=\frac{0,0698}{0,5529}=0,126
\end{aligned}
$$

\section{5). Biaya Energi PLTS (COE)}

Energi per hari $=($ Kapasitas Peak Panel Surya $\times 4)$

Energi per bulan $=$ Energi per hari $\times 30$

Energi per tahun $(\mathrm{kWh})=$ Energi per bulan $\times 12$

$$
\begin{aligned}
& =(200 \mathrm{wh} \times 4)=800 \mathrm{wh} \\
\mathrm{COE} & =\frac{L C C \times C R F}{k W h} \\
& =800 \mathrm{wh} \times 30 \times 12=288 \mathrm{kWh} \\
& \text { Rp. } 977,7 / \mathrm{kWh}
\end{aligned}
$$

7) Biaya Listrik PLN beban 450 VA

Dalam perbandingan TDL antara PLN dan PLTS, asumsi bahwa jumlah energi adalah sama sehingga dapat mengetahui biaya pada jumlah energi yang sama, yaitu 288 kWh. Harga per kWh pada listrik 450 VA adalah Rp. 415 (peraturan ESDM 2019, karena 2020 subsidi covid-19). Hal ini dapat diartikan bahwa jumlah energi $288 \mathrm{kWh}$ adalah jumlah pemakaian listrik PLN selama 10 tahun, dengan beban yang sama. Biaya listrik PLN = Jumlah energi $\mathrm{x}$ TDL per $\mathrm{kWh} x$

$$
\begin{aligned}
& {\left[\frac{(1+i)^{n}-1}{i(1+i)^{n}}\right]+(\text { abonemen } \times 12 \times 10) } \\
= & 288 \times \text { Rp. } 415+\left[\frac{(1+0,05)^{10}-1}{0,05(1+0,05)^{10}}\right]+(8000 \times 12 \times 10) \\
= & \text { Rp. } 1.079 .527,75
\end{aligned}
$$

Selisih pemasangan PLTS dan biaya listrik PLN selama 10 tahun Rp. 2.234.743,9 - Rp. 1.079.527,75 = Rp. 1.155.216.15

Pemasangan PLTS off-grid sesuai dengan modul pengujian panel surya $200 \mathrm{Wp}$ dibandingkan dengan tarif dasar listrik (TDL) yang paling mendekati adalah 450 VA. Dengan menggunakan PLTS off-grid diperoleh TDL per kWh adalah Rp. 977,7 sedangkan TDL PLN beban listrik 450 VA adalah Rp. 415. Berdasarkan analisa ekonomi pemasangan listrik PLTS akan nampak lebih mahal, hal ini karena listrik PLN mendapat subsidi 50\% dari pemerintah. Jika dalam pelaksanaannya listrik PLN tidak mendapat subsidi, maka TDL 450 VA adalah Rp. 830, lebih murah 147,7 dari pada listrik PLTS. Namun ini tidak bisa diperkirakan kenaikan TDL per tahun mengingat semakin langka bahan bakar untuk PLN. Untuk pemasangan listrik pada daerah 3T atau remote area, pemasangan listrik PLTS off-grid merupakan solusi untuk memenuhi kebutuhan tersebut. 


\subsection{Sistem Monitoring Berbasis IoT}

Proses pengambilan data pengujian dilakukan dengan skema berikut:

1. Melakukan uji coba monitoring PLTS sebanyak 5 percobaan dengan jarak yang sama untuk mengetahui kehandalan perangkat.

2. Melakukan 5 percobaan untuk pengambilan data jarak koneksi perangkat dengan pengguna untuk mengetahui jarak maksimal perangkat dapat bekerja.

Tabel 2. Data pengujian dalam jarak yang sama untuk uji nyala dari perangkat monitoring

\begin{tabular}{|c|l|l|}
\hline Percobaan ke- & Waktu delay & $\begin{array}{l}\text { Status } \\
\text { keberhasilan } \\
\text { Alat }\end{array}$ \\
\hline 1 & 3 Detik & Berhasil \\
\hline 2 & 4 Detik & Berhasil \\
\hline 3 & 3,5 Detik & Berhasil \\
\hline 4 & 3 Detik & Berhasil \\
\hline 5 & 4 Detik & Berhasil \\
\hline Rata-Rata & 3,5 Detik & Berhasil \\
\hline
\end{tabular}

Dari kelima percobaan yang telah dilakukan untuk mengetahui lama delay yang dibutuhkan alat untuk koneksi ke internet dan membaca data adalah rata-rata 3,5 detik dengan status keberhasilan $100 \%$.

Tabel 3. Data pengujian dalam jarak yang berbeda untuk uji jarak dari perangkat monitoring

\begin{tabular}{|c|l|l|}
\hline Percobaan ke- & Jarak Pengguna & $\begin{array}{l}\text { Status } \\
\text { keberhasilan Alat }\end{array}$ \\
\hline 1 & 300 meter & Berhasil \\
\hline 2 & 500 meter & Berhasil \\
\hline 3 & 600 meter & Berhasil \\
\hline 4 & 650 meter & Berhasil \\
\hline 5 & 700 meter & Berhasil \\
\hline
\end{tabular}

Pada Tabel 3 tersebut, modul pengujian PLTS diletakkan dengan jarak pengguna 300 meter, 500 meter, 600 meter, 650 meter, dan 700 meter. Dari pengujian yang dilakukan diperoleh data bahwa sejauh apapun pengguna melakukan monitoring, peralatan dapat membaca data dengan syarat ketersediaan jaringan internet.

Tabel 4. Data pengujian modul PLTS dengan sistem monitoring IoT

\begin{tabular}{|c|c|c|c|c|c|}
\hline Tanggal & Waktu & $\begin{array}{c}\text { Tegangan } \\
(\mathrm{V})\end{array}$ & $\begin{array}{c}\text { Arus } \\
(\mathrm{A})\end{array}$ & $\begin{array}{c}\text { Daya } \\
(\text { Watt })\end{array}$ & $\begin{array}{c}\text { Energi } \\
(\text { Kwh })\end{array}$ \\
\hline $18 / 04 / 2021$ & $12: 20: 28$ & 222.30 & 0.07 & 16.00 & 0.3530 \\
\hline $18 / 04 / 2021$ & $12: 20: 30$ & 224.30 & 0.07 & 16.20 & 0.3530 \\
\hline $18 / 04 / 2021$ & $12: 20: 32$ & 224.30 & 0.07 & 16.20 & 0.3530 \\
\hline $18 / 04 / 2021$ & $12: 20: 34$ & 224.40 & 0.07 & 16.20 & 0.3530 \\
\hline $18 / 04 / 2021$ & $12: 20: 36$ & 222.30 & 0.07 & 16.20 & 0.3530 \\
\hline $18 / 04 / 2021$ & $12: 25: 39$ & 217.40 & 0.14 & 30.90 & 0.3550 \\
\hline $18 / 04 / 2021$ & $12: 25: 41$ & 214.00 & 0.14 & 32.90 & 0.3550 \\
\hline $18 / 04 / 2021$ & $12: 25: 43$ & 214.00 & 0.14 & 32.90 & 0.3550 \\
\hline $18 / 04 / 2021$ & $12: 25: 46$ & 213.90 & 0.14 & 32.90 & 0.3550 \\
\hline $18 / 04 / 2021$ & $12: 25: 47$ & 213.90 & 0.14 & 32.90 & 0.3560 \\
\hline
\end{tabular}



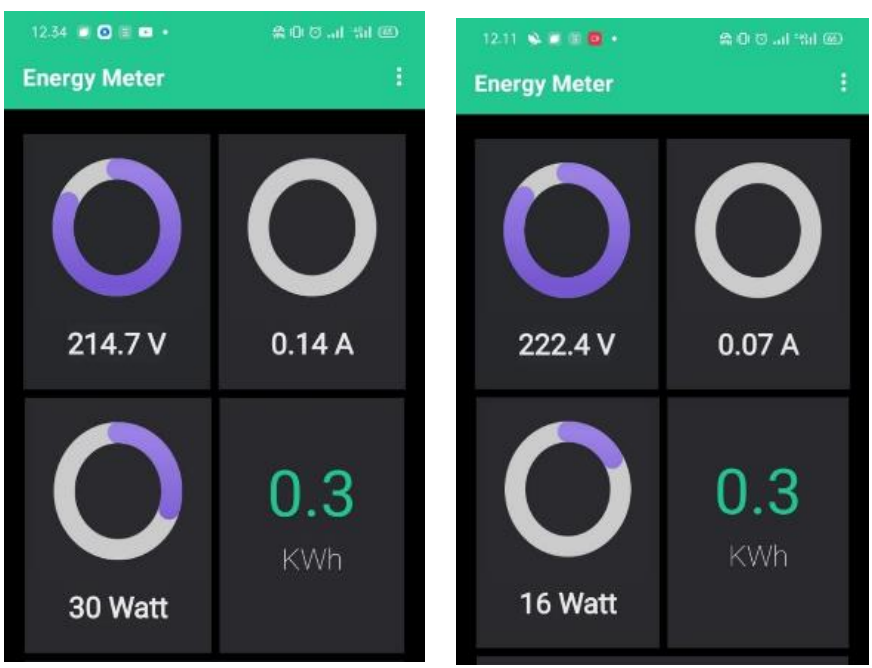

Gambar 10. Tampilan sistem IoT monitoring PLTS off-grid pada perangkat Andorid

Berdasarkan data hasil penelitian yang telah dilakukan pada Tabel 4 dan Gambar 10. Monitoring PLTS off-grid dapat dilakukan dengan baik, yaitu sistem dapat membaca data modul PLTS dengan pengguna menggunakan perangkat telpon android karena monitoring sudah support IoT.Dari perangkat ini pengguna dapat memantau performa PLTS dengan perangkat seluler dari jarak jauh sekalipun dengan syarat tersedia jaringan internet, sehingga jika perangkat terletak jauh dari BTS dan memiliki kekuatan sinyal internet yang rendah maka transfer data akan terganggu. Dari hasil PLTS off-grid diperoleh data bahwa tegangan keluaran inverter masih memasuki standart listrik PLN yaitu 220 volt $\mathrm{AC}$ dengan toleransi $\pm 10 \%$, nilai arus menunjukkan bahwa arus yang mengalir pada beban lampu sebesar 0,07 A pada beban 1 lampu dan 0,14 A pada beban 2 lampu. Dengan adanya penambahan beban lampu dapat ditunjukkan pada perubahan data arus dan daya antara 1 lampu dan 2 lampu. Dengan pengambilan data PLTS offgrid, dapat digambarkan bentuk simulasi pembangkit listrik pada remote area dengan komponen pendukung yang sama dengan PLTS off-grid.

\section{Kesimpulan}

Pemenuhan kebutuhan listrik pada daerah 3T menjadi sulit dilakukan jika harus menghubungkan jalur listrik pada daerah 3T atau remote area. Potensi sumber daya alam untuk dimanfaatkan sebagai sumber energi listrik terbarukan adalah solusi. Potensi cahaya matahari di Indonesia yang merupakan negara tropis dapat dimanfaatkan sebagai PLTS off-grid. Secara ekonomi, pemasangan instalasi PLTS off-grid lebih murah untuk umur hidup 10 tahun dan listrik PLN tidak mendapat subsidi 50\%. Saat ini listrik PLTS terkesan lebih mahal karena komponen penyusun tidak mendapatkan subsidi lebih dari pemerintah, sehingga kemandirian energi terihat lebih susah dan mahal. Selain itu pada penelitian ini, untuk memudahkan maintenance sistem PLTS off-grid yang dibangun, penelitian ini membangun sebuah sistem monitoring PLTS off-grid dengan teknologi IoT. Pengguna atau operator dapat memanfatkan fitur ini untuk memantau performa dari 
PLTS dari jarak manapun operator inginkan, hal ini karena sistem yang dibangun berbasis internet sehingga dapat secara langsung diakses selama tersedia jaringan internet. Berdasarkan sistem yang telah dibangun, sistem dapat menginformasikan data pengkuruan arus, tegangan, daya yang terkoneksi melalui telepon seluler. Untuk penelitian lebih lanjut, dapat dilakukan pada implementasi sistem monitoring PLTS offgrid dengan biaya perbandingan antara PLTS dengan listrik PLN. Hal ini akan memperlihatkan bagaimana aspek ekonomi dari pemasangan PLTS.

\section{Daftar Pustaka}

[1] M. Muchlis dan A. D. Permana. Proyeksi Kebutuhan Listrik PLN tahun 2003 s.d 2020., 2005.

[2] Cahya, "Analisa Performansi dan Monitoring Berbasis Web pada Pembangkit Listrik Tenaga Surya di Fakultas Teknologi Industri ITS," Undergraduate Thesis: Teknik Fisika ITS, 2017.

[3] A. K. Bahar dan A. T. Maulana, "Perencanaan dan Simulasi Sistem PLTS Off-grid Untuk Penerangan Gedung Fakultas Teknik UNKRIS," Jurnal Ilmiah Elektrokrisna, vol. 6 no. 3, 97-107, 2018.

[4] S. Samara and E. Natsheh, "Intelligent Real-Time Photovoltaic Panel Monitoring System Using Artificial Neural Networks," IEEE Access, vol.7, 2019.

[5] A. Calazans, et al., "Economis Analysis of a Photovoltaic System Connected to The Grid in Recife, Brazil," Proc. of IEEE 42nd Photovoltaic Specialist Conference, New Orleans, June 2015.

[6] G. Corira, F. Penizzotto, and R. Pringles, "Economic Analysis of Rooftop Solar PV System in Argentina," IEEE Latin America Transactions, vol. 18, no. 1, 32-42, January 2020

[7] H. Satria dan Syafii, "Sistem Monitoring Online dan Analisa Performansi PLTS Rooftop Terhubung ke Grid PLN," Jurnal Rekayasa Elektrika, vol. 14, no. 2, pp. 136144, 2018.

[8] R. I. S. Pereira, et al., "IoT Network and Sensor Signal for Meteorogizal Data and Photovoltaic Module Temperature Monitoring," IEEE Latin America Transactions, vol. 17, no 6, pp. 937-944, June 2019

[9] E. G. Bi, F. Monette, and J. Gasperi, "Analysis of the influence of rainfall variables on urban effluents concentrations and fluxes in wet weather," J. Hydrol., vol. 523, pp. 320-332, 2015.

[10] K. Khalil, K. Elgazzar, M. Seliem, and M. Bayoumi, "Resource Discovery Techniques in the Internet of Things: A Review," Internet of Things, vol.12, 2020. 